\title{
Two new species of Neoentobdella (Monogenea: Capsalidae: Entobdellinae) from the skin of Australian stingrays (Dasyatidae)
}

\author{
Ian D. Whittington ${ }^{1,2}$ and Graham C. Kearn $^{3}$ \\ ${ }^{1}$ Monogenean Research Laboratory, Parasitology Section, The South Australian Museum, North Terrace, Adelaide, South Australia \\ 5000, Australia; \\ ${ }^{2}$ Marine Parasitology Laboratory, School of Earth and Environmental Sciences (DX 650 418), The University of Adelaide, North \\ Terrace, Adelaide, South Australia 5005, Australia; \\ ${ }^{3}$ School of Biological Sciences, University of East Anglia, Norwich, Norfolk, NR4 7TJ, UK
}

\begin{abstract}
Two new species of entobdelline (capsalid) monogeneans are described from the skin of Australian dasyatid stingrays, namely Neoentobdella cribbi sp. n., a small parasite from the estuarine stingray, Dasyatis fluviorum Ogilby (Elasmobranchii: Dasyatidae) and Neoentobdella baggioi sp. n., a relatively large parasite from the porcupine ray, Urogymnus asperrimus (Bloch et Schneider) (Elasmobranchii: Dasyatidae). A striking feature of both of these new parasite species is a pad, possibly located within the genital atrium, armed with rows of closely spaced, rod-shaped microsclerites. Both species also possess a muscular papilla in the genital tract and a club-shaped structure near the common genital opening on the left lateral margin of the body. In N. cribbi, the latter feature is large and located anterior to the genital pad and in N. baggioi, it is small and located in a more posterior position. Similar embellishments in the genital area occur in N. natans Kearn et Whittington, 2005 and in N. parvitesticulata Kearn et Whittington, 2005, while other species (e.g. N. garneri Whittington et Kearn, 2009 and N. taiwanensis Whittington et Kearn, 2009) lack these features and differ also in functional aspects of the male copulatory apparatus and the haptor. Separate generic status for these two groupings is indicated, but must await a comparative and comprehensive review of all Neoentobdella spp.
\end{abstract}

Key words: Platyhelminthes, Monogenea, entobdellines, Neoentobdella cribbi sp. n., Neoentobdella baggioi sp. n., Dasyatidae, stingrays, Dasyatis fluviorum, Urogymnus asperrimus, spermatophores

Neoentobdella spp. are entobdelline (capsalid) monogeneans living on the skin of stingrays (Elasmobranchii). While examining freshly caught estuary stingrays, Dasyatis fluviorum Ogilby (Dasyatidae) off Stradbroke Island, Queensland, Australia, Dr. Tom Cribb (University of Queensland) found several entobdelline monogeneans on the ventral surfaces and kindly donated these specimens to us. Entobdelline monogeneans were also collected from another dasyatid, namely the porcupine ray, Urogymnus asperrimus (Bloch et Schneider) (Dasyatidae), collected on Sudbury Reef, an inshore reef south-east of Cairns, Queensland, Australia by staff of Cairns Marine Aquarium Fish, Cairns. These parasites were collected by Mr. Julian Baggio (Senior Aquarist at this facility) and sent to us for study. A preliminary examination revealed novel anatomical features indicating that the parasites had not previously been described and prompted us to study their anatomy in detail.

\section{MATERIALS AND METHODS}

Parasites preserved in $10 \%$ formalin were later stained with Semichon's carmine or left unstained. The specimens were dehydrated in an ethanol series, cleared in cedarwood oil and mounted in Canada balsam. Whole mounts were studied using a compound microscope equipped with phase contrast optics. Measurements, made using a calibrated ocular micrometer, were restricted to unfolded, flattened specimens, are presented in micrometres as the mean followed by the range in parentheses and the number of measurements taken. Where measurements are presented in paired sets separated by a multiplication sign, the first is length and the second is width. Haptoral terminology for capsalids follows Whittington et al. (2001).

\section{RESULTS}

Capsalidae Baird, 1853

Entobdellinae Bychowsky, 1957 (as amended by

Kearn and Whittington 2005)

Neoentobdella Kearn et Whittington, 2005

Neoentobdella cribbi sp. $\mathrm{n}$.

Figs. 1, 2

Description. Based on six flattened specimens (five adults; one juvenile). Total length and breadth of three adults: $4788(3895-5715) \times 1975$ (1594-2346). Haptor length and breadth: $1522(1354-1690)(2) \times 1353(1233-$

Address for correspondence: I. Whittington, Monogenean Research Laboratory, Parasitology Section, The South Australian Museum, North Terrace, Adelaide, South Australia 5000, Australia. Phone: ++61 88207 7463; Fax: ++61 88207 7222; E-mail: whittington.ian@saugov.sa.gov.au 


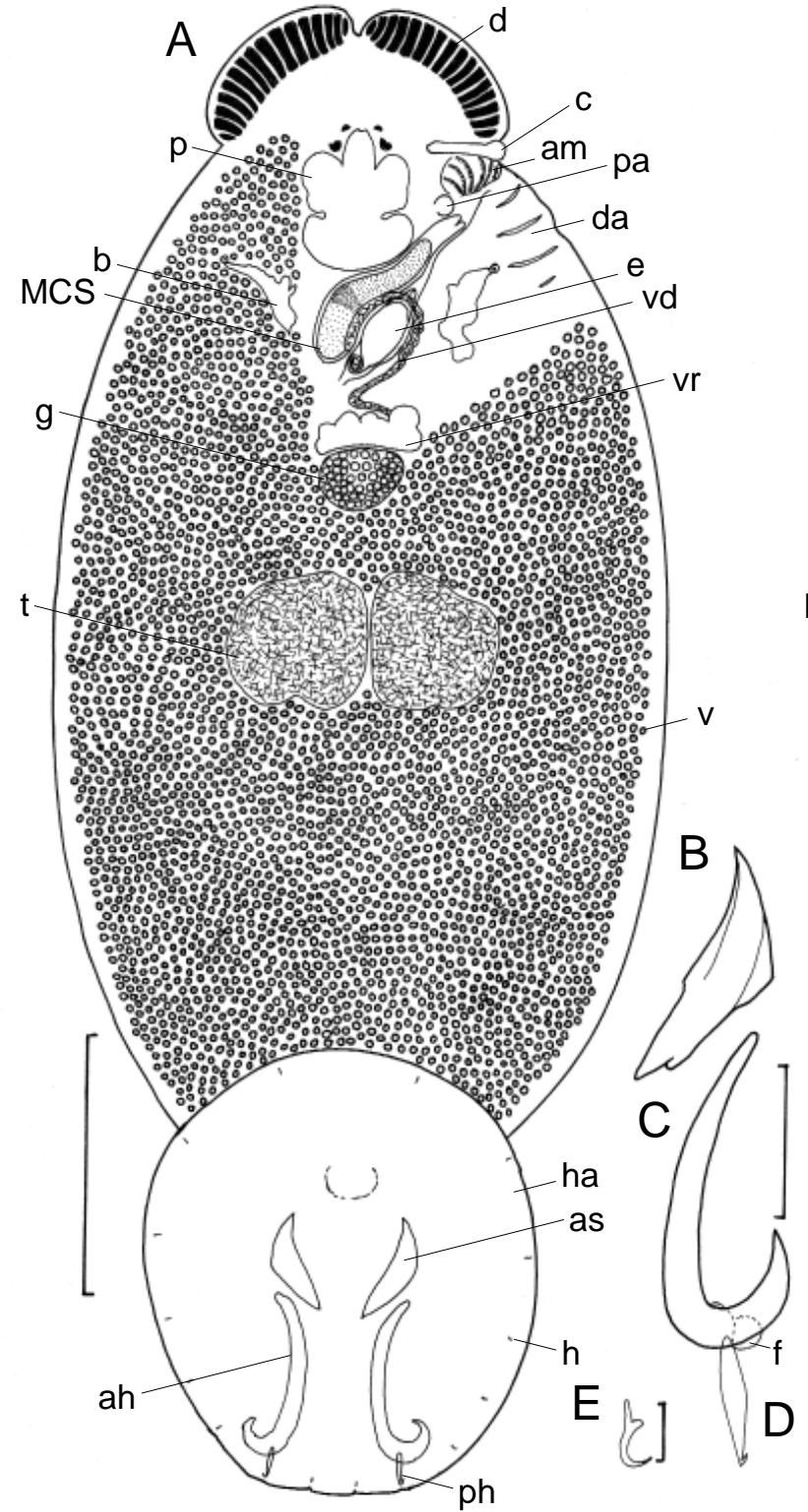

Fig. 1. Neoentobdella cribbi sp. n. A - whole animal in ventral view, based on holotype and paratypes; $\mathbf{B}$ - accessory sclerite; C - anterior hamulus; D - posterior hamulus; B, C and D drawn in positions relative to each other as occupied in the haptor; $\mathbf{E}$ hooklet. Abbreviations: ah - anterior hamulus; am - array of microsclerites; as - accessory sclerite; b - bladder; c - club-shaped organ; d - 'diadem'; da - grooved/folded dorsal area; e - egg in ootype; $f$ - circular flap associated with site of emergence of point of anterior hamulus from haptor; $g$ - germarium; $h-$ hooklet; ha - haptor; MCS - male copulatory sac; $p$ - pharynx; pa - papilla; $\mathrm{ph}$ - posterior hamulus; $\mathrm{t}$ - testis; $\mathrm{v}$ - vitellarium; $\mathrm{vd}$ - vas deferens; $\mathrm{vr}-$ vitelline reservoir. Scale bars: $A=1 \mathrm{~mm}$; $\mathrm{B}, \mathrm{C}, \mathrm{D}=250 \mu \mathrm{m} ; \mathrm{E}=20 \mu \mathrm{m}$.

1534) (3). Length of median haptoral sclerites: accessory sclerites 386 (337-431) (6) (Fig. 1B); anterior hamuli 520 (415-627) (4) (Fig. 1C); posterior hamuli 173 (170-182) (4) (Fig. 1D). Hooklets with relatively short "handle"; to-

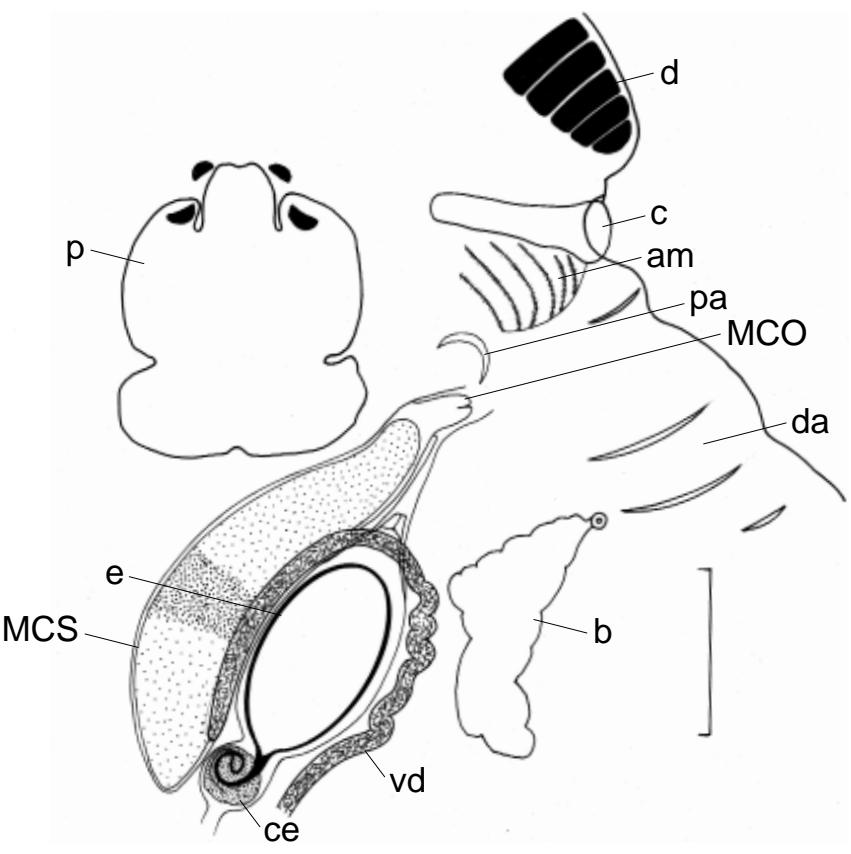

Fig. 2. Neoentobdella cribbi sp. $\mathrm{n}$. Anterolateral region of body (left side) in ventral view showing details of the reproductive system. Abbreviations: ce - cement; MCO - male copulatory organ. Other abbreviations as in Fig. 1. Scale bar $=250 \mu \mathrm{m}$.

tal hooklet length 26 (25-28) (5) (Fig. 1E). Distal tips of accessory sclerites and anterior hamuli frequently missing. In comparison with shafts of anterior hamuli of other entobdellines, those of $N$. cribbi noticeably more curved when viewed from lateral direction. Roughly circular flap of tissue (diameter approximately 50) located in region of emergence of anterior hamulus point from haptor tissue (Fig. 1C). Tendons, associated in other entobdelline monogeneans with accessory sclerites and anterior hamuli (see Kearn et al. 2007), not observed. Marginal valve absent.

Adhesive pads on anterolateral borders of head region subdivided to form "diadem" (see Llewellyn and Euzet 1964); each pad comprising 15-17 flat, slightly elevated transverse rays (Fig. 1A), similar to those of $N$. natans (see Kearn and Whittington 2005), but unlike N. natans incomplete rays rare or absent. Eye spots present, conspicuous; each eye spot associated with inconspicuous transparent vesicle. Each bladder opens dorsally via small papilla. Pharynx 407 (361-475) (3) × 359 (329-419) (3) Intestinal caeca obscured by vitellarium; unclear whether caeca unite posteriorly.

General arrangement of reproductive organs and associated ducts as in other entobdellines (see, for example, $N$. natans, as described and illustrated by Kearn and Whittington 2005, figs. 2, 6). Testes dimensions: 522 (455-572) (6) $\times 481(392-557)(6)$; testes slightly lobed but lacking deep marginal indentations. Glands of Goto not observed in adults or in juvenile. Male copulatory organ (MCO) 
short with little scope for eversion and therefore probably a penis, with relatively long male copulatory sac (MCS) extending to level of posterior end of ootype (Figs. 1A, 2). No conspicuous layer of longitudinal (muscle?) fibres in wall of MCS. MCS containing abundant accessory gland secretion, varying in texture along its length. Source of male accessory gland secretion uncertain but ducts beneath MCS lack stain, as does accessory gland reservoir within MCS, hence ducts may transport accessory gland secretion to MCS from unknown source. Region of vas deferens running anteriorly alongside ootype convoluted, then turns in median direction, crosses anterior region of ootype, turns in posterior direction in association with MCS, but point of entry into MCS not determined. MCO lying in canal receiving short uterus laterally (Fig. 2). In one adult, MCO deflected into uterus. Relatively large muscular papilla located in common genital tract just distal to MCO (Fig. 2). Common genital opening on left margin of body. Muscular pad anterior to penis armed with six (possibly more) curved rows of closely spaced short rods, resembling teeth of comb and presumed to be sclerotised (= microsclerites) (Figs. 1A, 2). Pad bearing microsclerites may lie inside genital atrium. Large club-shaped organ on body margin, anterior to pad bearing microsclerites; diameter of terminal swelling of club-shaped organ 81 (60-94) (5). Posterior to microsclerite-bearing pad, dorsal surface of parasite bears three or four parallel linear features (grooves or folds?; Fig. 2); no vitelline follicles lie beneath this area (Fig. 1A). In two adult specimens, granular structure (spermatophore (?); not illustrated) attached to this dorsal grooved or folded area.

Female reproductive system as in $N$. natans (see Kearn and Whittington 2005, fig. 6). Vagina not identified. Vitelline reservoir lobed; in juvenile specimen, vitelline reservoir empty but lobes already present (paratype No. AHC 29543). On right side of body, vitellarium extends anteriorly to level of anterior margin of pharynx (Fig. 1A); on left side of body, vitellarium extends anteriorly no further than level of posterior region of bladder. Vitelline follicles noticeably absent in vicinity of common genital opening and associated structures (club-shaped organ, muscular papilla, microsclerite rows, dorsal grooves/folds). Egg ovoid; dimensions measured in ootype: capsule length 274 (1); short coiled appendage (Fig. 2) 300 (1) long (estimation). Granular material associated with appendage tip probably cement.

Differential diagnosis. Neoentobdella cribbi is distinguished from other species of Neoentobdella, with the exception of $N$. natans Kearn et Whittington, 2005, N. parvitesticulata Kearn et Whittington, 2005 and N. baggioi sp. n. (see below), by the presence of embellishments (clubshaped organ, muscular papilla in common genital tract, genital pad with microsclerites, dorsal grooves/folds) in the region of the left side of the body where the genital ducts open. However N. cribbi can be distinguished from
$N$. natans, $N$. parvitesticulata and $N$. baggioi sp. n. by the presence of a large club-shaped organ (average diameter of terminal swelling 81) projecting laterally on the left side from the region anterior to the genital pad bearing microsclerites. Neoentobdella natans and $N$. baggioi sp. $\mathrm{n}$. have similar organs but these are smaller (diameter of terminal swelling 31 in $N$. baggioi sp. n.) and are located more posteriorly (see Kearn and Whittington 2005 and below). In comparison with the shafts of the anterior hamuli of other entobdellines, those of $N$. cribbi are noticeably more curved when viewed from a lateral direction. Neoentobdella cribbi inhabits the ventral skin of the estuarine stingray, Dasyatis fluviorum.

Type host: Dasyatis fluviorum Ogilby (Dasyatidae), the estuarine stingray.

Type locality: Moreton Bay, near Dunwich, Stradbroke Island (27 $\left.15^{\circ} \mathrm{S}, 153^{\circ} 15^{\prime} \mathrm{E}\right)$, Queensland, Australia.

Site on host: Ventral skin surface.

Type material: Holotype deposited in the Australian Helminthological Collection (AHC) of the South Australian Museum (SAMA), North Terrace, Adelaide, South Australia 5000, Australia (contact: Leslie Chisholm - chisholm. leslie@saugov.sa.gov.au) (AHC 29542); three paratypes in SAMA (AHC 29543-29545); two paratypes deposited in the Queensland Museum (QM), PO Box 3300, South Brisbane, Queensland 4101, Australia (contact: Rob Adlard - Robert. Adlard@qm.qld.gov.au) (QM G 230665-G 230666).

Etymology: The species is named after Dr. Tom Cribb (School of Molecular and Microbial Sciences, The University of Queensland, Brisbane, Queensland, Australia) who collected the parasite specimens in April 2004.

\section{Neoentobdella baggioi sp. $\mathrm{n}$.}

Figs. 3, 4

Description. Based on two flattened, adult specimens, one stained in carmine, one unstained. Total length and breadth: $10930(9480-12390)(2) \times 5400(4960-5840)$ (2). Haptor length and breadth: 3190 (2770-3610) (2) $\times 3460$ ( 1 only; haptor edge folded). Length of median haptoral sclerites: accessory sclerites 545 (447-663) (4) (Fig. 3B); anterior hamuli 776 (631-906) (4) (Fig. 3C). Posterior hamuli distorted or obscured (not drawn enlarged); estimated length 65 (57-77) (3). Hooklets with relatively short "handle"; length of flat hooklet 19 (1) (Fig. 3D). No circular flap detected in association with protrusion of anterior hamulus points from haptor tissue. Tendons associated with accessory sclerites present (Fig. $3 \mathrm{~A}$ ), but insertion site after passage through notch in accessory sclerite not determined. Marginal valve present but narrow and inconspicuous.

Adhesive pads on anterolateral borders of head region subdivided to form "diadem", each pad comprising 17 to 19 flat, slightly elevated transverse rays (Fig. 3A). Incomplete rays hard to identify in three of four pads available for study, but in fourth pad six incomplete rays occupying spaces between outer regions of complete rays observed. 


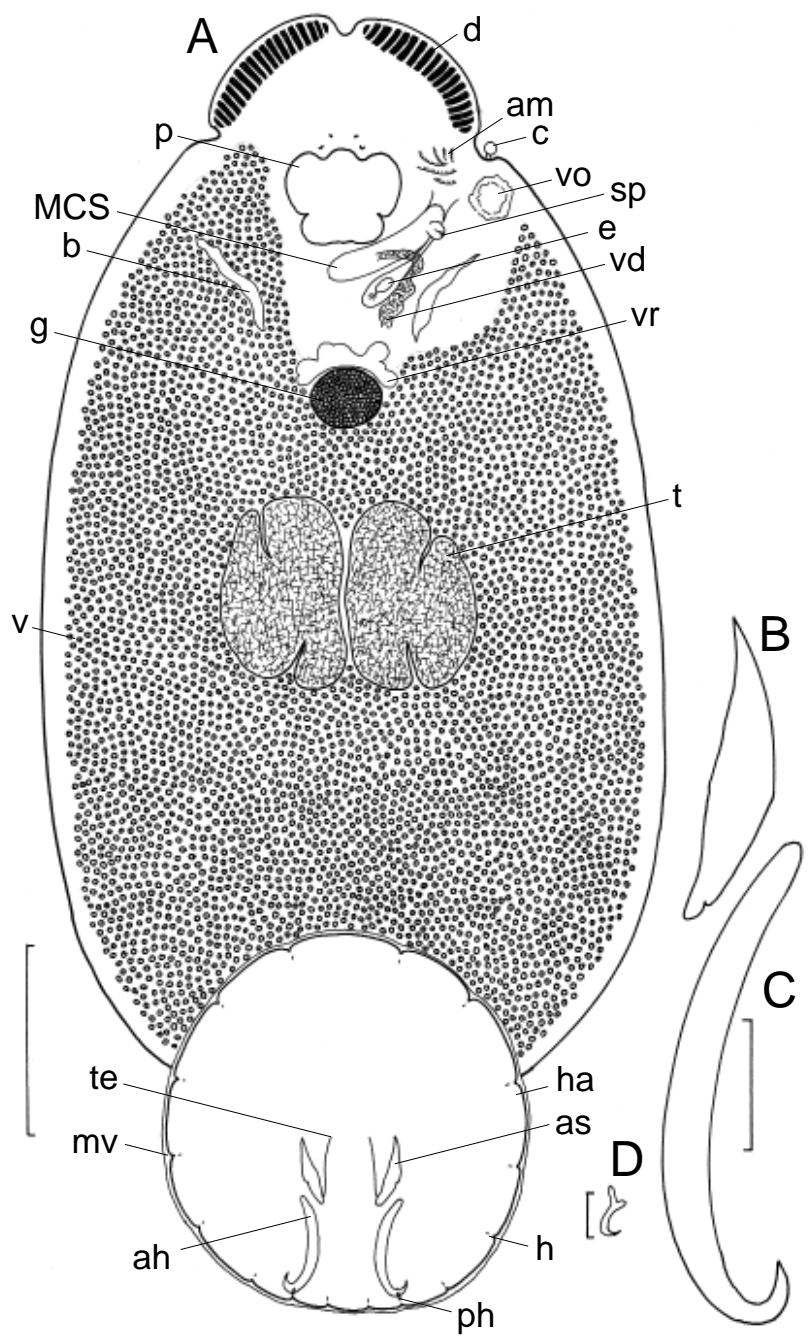

Fig. 3. Neoentobdella baggioi sp. n. A - whole animal in ventral view based on the holotype and paratype; $\mathbf{B}$ - accessory sclerite; C - anterior hamulus; D - hooklet. Posterior hamuli not illustrated enlarged because of distortion or obscurity. Abbreviations: $\mathrm{mv}$ - marginal valve; sp - sucker-like papilla; te - tendon; vo presumed vaginal opening obscured by presence of mass of material (presumed attached spermatophore?). Other abbreviations as in Fig. 1. Scale bars: A $=2 \mathrm{~mm} ; \mathrm{B}, \mathrm{C}=250 \mu \mathrm{m} ; \mathrm{D}=15 \mu \mathrm{m}$.

Eye spots present, conspicuous, each one associated with transparent vesicle. No papillae observed dorsally at opening of excretory bladder. Pharynx 933 (842-1023) $(2) \times 933(812-1053)(2)$. Intestinal caeca obscured by vitellarium; unclear whether caeca unite posteriorly.

General arrangement of reproductive organs and associated ducts as in N. cribbi (see above and Figs. 3A, 4). Testes dimensions: $1632(1414-1895)(4) \times 1264$ (1113-1384) (4), each with one anterior and one posterior deep marginal indentation (Fig. 3A). Glands of Goto not observed. Common genital tract houses two papilla-like organs, one presumably the MCO (probably a penis), the other situated lateral and slightly proximal to penis resembling a sucker (requires clarification with more speci-

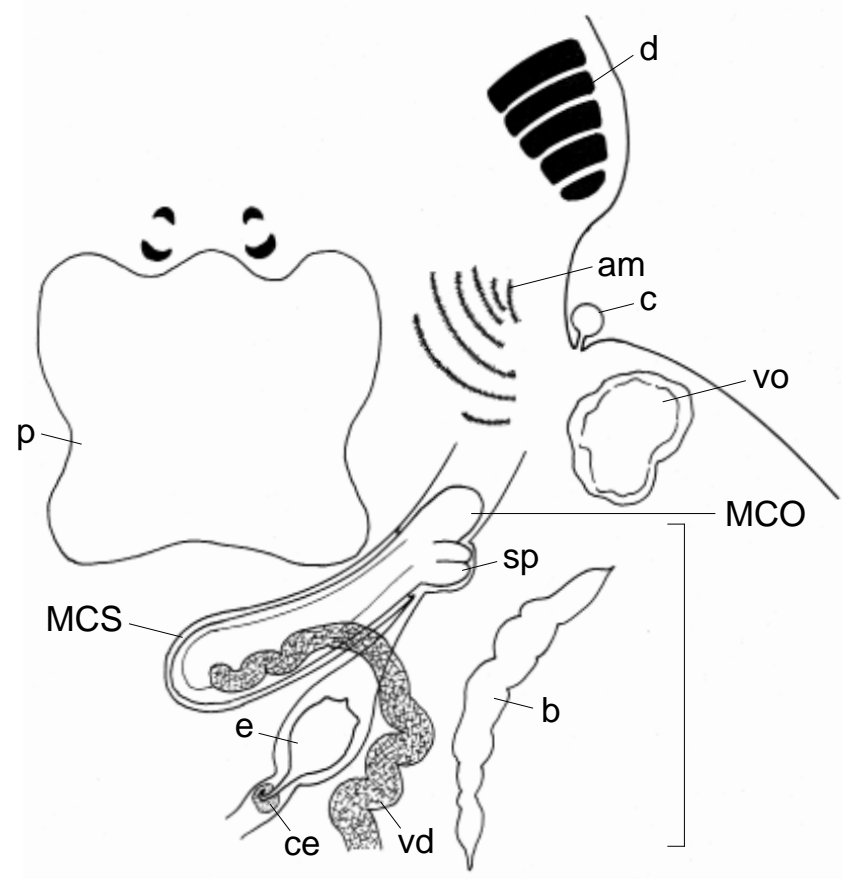

Fig. 4. Neoentobdella baggioi sp. n. Anterolateral region of body (left side) in ventral view showing details of the reproductive system. Abbreviations as in Figs. 1, 2, 3. Scale bar $=1 \mathrm{~mm}$.

mens). No conspicuous layer of longitudinal (muscle?) fibres in wall of MCS. Region of vas deferens running anteriorly alongside ootype convoluted and capacious in both specimens; point of entry into MCS lateral (Figs. 3, 4). Large, possibly dorsal, opening (vaginal opening (?); see Discussion) on left margin of body, accommodating in both specimens mass of material that may represent spermatophore (Figs. 3, 4; see Discussion). Club-shaped organ (diameter of terminal swelling 31) lying anterior to this opening seen in holotype only (Figs. 3A, 4); possibly obscured by "spermatophore" in paratype. At level of club-shaped organ, muscular pad that may lie inside genital atrium, armed with 6 (holotype) and 7 (paratype) curved rows of closely spaced microsclerites, resembling teeth of comb (Figs. 3A, 4). Features of dorsal surface in region of presumed vaginal opening obscured by presence of mass of material (spermatophore (?); Figs. 3, 4).

Female reproductive system as in N. cribbi (see above). Vagina not identified, apart from possible dorsal opening (see above). Vitelline reservoir lobed (Fig. 3A). Distribution of vitelline follicles similar to that in $N$. cribbi. Anterior extension of follicles restricted on left side, not extending anterior to vitelline reservoir medianly, but almost reaching presumed dorsal vaginal opening near lateral region of body (Fig. 3A). On right side, vitelline follicles extend to level of eye spots. Each adult with egg in ootype; egg capsule 251 (1) long; appendage short 102 (1) long, with single terminal globule (cement (?); Fig. 4); in carmine-stained individual, globule has affinity for stain. 
Differential diagnosis. Neoentobdella baggioi is distinguished from other known species of Neoentobdella, with the exception of $N$. natans, $N$. parvitesticulata and $N$. cribbi (see above), by the presence of embellishments (club-shaped organ, sucker-like papilla adjacent to the $\mathrm{MCO}$, genital pad with rows of microsclerites) in the region of the left side of the body where the genital ducts open. Neoentobdella baggioi is significantly larger than $N$. cribbi (see above), N. natans and N. parvitesticulata (see Kearn and Whittington 2005). In addition to its greater size, N. baggioi can be distinguished from N. cribbi by the presence of a relatively small club-shaped organ (diameter of terminal swelling 31), situated more posteriorly than the larger club-shaped organ (average diameter of terminal swelling 81) of $N$. cribbi. The microsclerites in $N$. natans resemble shark denticles, while those of $N$. baggioi are short rods resembling the teeth of a comb. Neoentobdella parvitesticulata has no club-shaped organ and $N$. baggioi also differs from $N$. parvitesticulata in the large size of the indented testes (average length 1632 versus 332; see Kearn and Whittington 2005). There is no sucker-like papilla in the common genital tract of $N$. parvitesticulata. Neoentobdella baggioi inhabits the skin of the porcupine ray, Urogymnus asperrimus.

Type host: Urogymnus asperrimus (Bloch et Schneider) (Dasyatidae), the porcupine ray.

Type locality: Sudbury Reef $\left(17^{\circ} 00^{\prime} \mathrm{S}, 146^{\circ} 12^{\prime} \mathrm{E}\right)$, an inshore reef south east of Cairns, Queensland, Australia.

Site on host: Skin surfaces of a single specimen weighing approximately $70 \mathrm{~kg}$. Entobdellines were first noticed after the ray was treated briefly with fresh water before being placed in a holding tank at Cairns Marine Aquarium Fish, Cairns, Queensland, Australia.

Prevalence data: Two adult specimens collected from single host.

Type material: Holotype (AHC 29546) and one paratype (AHC 29547) deposited in SAMA.

Etymology: The species is named after Mr. Julian Baggio (Senior Aquarist, Cairns Marine Aquarium Fish, Cairns, Queensland, Australia) who collected this species during freshwater treatment of a single porcupine ray.

\section{DISCUSSION}

Neoentobdella cribbi from the ventral skin of the estuarine stingray Dasyatis fluviorum and N. baggioi from the skin of the porcupine ray, Urogymnus asperrimus, are described. These parasites are similar to each other and to $N$. natans and $N$. parvitesticulata described by Kearn and Whittington (2005). Notable anatomical features of $N$. cribbi include a pad armed with rows of microsclerites, probably located inside the genital atrium, a large club-shaped organ anterior to the genital pad, a muscular papilla in the distal region of the common genital tract and parallel linear features (grooves/folds) on the dorsal surface of the parasite posterior to the genital pad. Nota- ble features of $N$. baggioi include its large size, a genital pad bearing microsclerites probably located inside the genital atrium, a small club-shaped organ associated with the common genital opening and a muscular sucker-like papilla in the common genital tract. Corresponding structures are present in N. natans and N. parvitesticulata, except for the club-shaped organ and the muscular papilla, which are absent in N. parvitesticulata. The club-shaped organ of $N$. natans is similar in size and position to that of $N$. baggioi, while that of $N$. cribbi is larger and in a different location. The microsclerites on the genital pad resemble shark denticles in $N$. natans but resemble the teeth of a comb in N. cribbi, N. baggioi and N. parvitesticulata. The embellishments on the dorsal surface are parallel features (grooves/folds) in $N$. natans and $N$. cribbi and irregular folds with a labyrinthine appearance in N. parvitesticulata. Only two adult specimens of $N$. baggioi were available and in both of these, the dorsal surface posterior to the genital pad is obscured by an object that may be a spermatophore. A discussion of the possible roles of these varied embellishments in mating and in handling of spermatophores and eggs is presented in Kearn and Whittington (2005).

In N. natans, Kearn and Whittington (2005) reported the presence of a granular mass, resembling the contents of the male accessory gland reservoir, attached to the fleshy folded region on the dorsal surface of the genital area. They suggested that this object may be a spermatophore. This suggestion is supported by the finding in our present study of similar masses of material attached to the dorsal grooved/folded surface of two of our adult specimens of $N$. cribbi and to the corresponding dorsal surface in both of our adult specimens of $N$. baggioi. If these assumptions are correct and these objects are spermatophores, then they resemble more closely the jelly-like spermatophores of Entobdella soleae (see Kearn 1970) than the encased spermatophores of Neoentobdella diadema and N. garneri (see Kearn et al. 2006 and Whittington and Kearn 2009, respectively).

In $N$. baggioi, each of these roughly circular masses is lodged in a widely open aperture, apparently on the dorsal surface. Tentatively it is suggested that this dorsal aperture is the vaginal opening and that the mass of material lodged in each opening is a spermatophore that has been received from another parasite. The rest of the vagina was not identified in $N$. baggioi and no trace of it was found in N. cribbi. However, in N. natans and N. parvitesticulata, the proximal region of the vagina is narrow and hard to follow and distally could not be traced and the distal opening was not observed (Kearn and Whittington 2005), so it could have been inconspicuous and overlooked in N. cribbi and N. baggioi.

The male copulatory apparatuses of $N$. cribbi and $N$. baggioi differ in important ways from those of $N$. garneri and $N$. taiwanensis described by Whittington and 
Kearn (2009). In whole mounts of $N$. cribbi, the male copulatory organ (MCO) resembles a penis and varies little in length, while in whole mounts of $N$. garneri and $N$. taiwanensis, the MCO length varies from individual to individual (Whittington and Kearn 2009). It has been suggested by Whittington and Kearn (2009) that the MCOs of $N$. garneri and $N$. taiwanensis, although resembling a penis even at their shortest extension, also have the ability to change length in the manner of a cirrus, eversion probably being brought about by contraction of a conspicuous layer of fibres (muscle?) running in a longitudinal direction in the wall of the male copulatory sac (MCS). These sacs are sufficiently long to accommodate the retracted portion of the MCOs. No such fibre layer occurs in the wall of the MCS of $N$. cribbi or in that of N. baggioi, and limited space in the MCS provides little scope for retraction and eversion of a cirrus - most of the MCS of $N$. cribbi is filled with accessory gland secretion (Fig. 2). Consequently the MCOs of $N$. cribbi and $N$. baggioi most probably function as penises.

Differences, which could be regarded as degenerative, were detected in the tendon/accessory sclerite/anterior hamulus system between some species of Neoentobdella. In $N$. natans, the tendons are conspicuous but do not attach to the proximal ends of the anterior hamuli (Kearn and Whittington 2005), as they do, for example, in Entobdella soleae (see Kearn 1964) and the marginal valve, although present, is inconspicuous and narrow. In $N$. parvitesticulata, the tendons are present and attach to the anterior hamuli but they are slender and inconspicuous and there is no marginal valve (Kearn and Whittington 2005). In N. cribbi, tendons were not observed and the marginal valve is absent (Fig. 1). In N. baggioi, the tendons are relatively slender and the destination of the tendons after passing through the notches in the accessory sclerites is not clear (Fig. 3). Furthermore, although the marginal valve is present, it is narrow (Fig. 3). In E. soleae, intrinsic muscles are known to generate haptor suction independently of the extrinsic muscle/tendon/ sclerite suction system (Kearn 1988) and it is possible that four Neoentobdella species (N. baggioi, N. cribbi, N. natans and $N$. parvitesticulata) have favoured the intrinsic muscle system for generating suction at the expense of the extrinsic muscle/tendon/sclerite system. However, the reduction or loss of the marginal valve in these species of Neoentobdella seems to indicate a general loss of reliance on suction as an adhesive mechanism. Other monogeneans that have no marginal valve, such as Neocalceostomoides brisbanensis (see Kearn et al. 1995), appear to rely on adhesive secretion rather than suction for haptor attachment. Among capsalids, Whittington and Kearn (2008) provided evidence that Trimusculotrema heronensis, which has significantly reduced median haptor scler- ites, no extrinsic muscle/tendon system and no marginal valve, may use adhesive for haptor attachment, but there is no evidence that these four Neoentobdella species cement their haptors to the host.

In $N$. garneri and $N$. taiwanensis, there is no evidence for reduction in the tendon/accessory sclerite/anterior hamulus system and the marginal valve is present (Whittington and Kearn 2009). This difference between, on the one hand, N. garneri and N. taiwanensis and, on the other hand, N. baggioi, N. cribbi, N. natans and N. parvitesticulata, coupled with the functional difference between these two groups of species in the male copulatory apparatus and in other features of the reproductive system, reveals a diversity within Neoentobdella spp. that may deserve recognition by separate generic status. However this requires a comparative survey of all parasite species currently accommodated in Neoentobdella, an analysis that was beyond the scope of the current investigation.

In one of the preserved adult specimens of $N$. cribbi, the penis appeared to be deflected into the uterus, raising the possibility that self-insemination may occur in this species. This was also observed in a juvenile $N$. natans by Kearn and Whittington (2005) and had been previously described in juvenile Benedeniella macrocolpa and B. posterocolpa (see Kearn and Whittington 1992). Most monogeneans are protandrous, so it is possible for sperm introduced into the uterus of juveniles in which only the male system is functional to reach the oviduct and the fertilisation chamber in the germarium. It is less easy to see how successful self-insemination could be achieved in fully mature egg-producing individuals. We believe we have identified the vaginal opening on the dorsal surface of $N$. baggioi, and a vagina is present in $N$. natans and in N. parvitesticulata, but Kearn and Whittington (2005) noted that the vagina is hard to trace in whole mounts of the two last-named species. We may have overlooked it in $N$. cribbi and sectioning is required to confirm its presence.

Neoentobdella natans and N. parvitesticulata are able to swim freely (Kearn and Whittington 2005). Observations on live specimens of $N$. cribbi and $N$. baggioi are required to determine whether or not they have the ability to swim.

Acknowledgements. We are indebted to Dr. Tom Cribb (The University of Queensland) and Mr. Julian Baggio (Cairns Marine Aquarium Fish) for bringing the monogeneans described herein to our attention. We thank Dr. Leslie Chisholm and Dr. Vanessa Glennon (Marine Parasitology Laboratory, The University of Adelaide) for specimen preparation. This study was supported in part by Australian Research Council grant No. DP0556780 (2005-2007) awarded to IDW and Steve Donnellan (Evolutionary Biology Unit, The South Australian Museum). 


\section{REFERENCES}

KEARn G.C. 1964: The attachment of the monogenean Entobdella soleae to the skin of the common sole. Parasitology 54: 327-335.

KEARN G.C. 1970: The production, transfer and assimilation of spermatophores by Entobdella soleae, a monogenean skin parasite of the common sole. Parasitology 60: 301-311.

KeARn G.C. 1988: Orientation and locomotion in the monogenean parasite Entobdella soleae on the skin of its host (Solea solea). Int. J. Parasitol. 18: 753-759.

Kearn G.C., Whittington I.D. 1992: Diversity of reproductive behaviour in platyhelminth parasites: insemination in some benedeniine (capsalid) monogeneans. Parasitology 104: 489496.

Kearn G.C., Whittington I.D. 2005: Neoentobdella gen. nov. for species of Entobdella Blainville in Lamarck, 1818 (Monogenea, Capsalidae, Entobdellinae) from stingray hosts, with descriptions of two new species. Acta Parasitol. 50: 32-48.

Kearn G.C., Whittington I.D., Euzet L. 2006: The handling and fate of spermatophores in Neoentobdella diadema and N. apiocolpos (Monogenea: Capsalidae: Entobdellinae). Folia Parasitol. 53: 57-62.

Kearn G.C., Whittington I.D., Evans-Gowing R. 1995: Use of cement for attachment in Neocalceostomoides brisbanensis, a calceostomatine monogenean from the gill chamber of the blue catfish, Arius graeffei. Int. J. Parasitol. 25: 299-306.
Kearn G.C., Whittington I.D., Evans-Gowing R. 2007: A revision of Entobdella Blainville in Lamarck, 1818, with special emphasis on the nominal (type) species "Entobdella hippoglossi (Müller, 1776) Blainville, 1818” (Monogenea: Capsalidae: Entobdellinae) from teleost flatfishes, with descriptions of three new species and a new genus. Zootaxa 1659: 1-54.

Llewellyn J., Euzet L. 1964: Spermatophores in the monogenean Entobdella diadema Monticelli from the skin of sting-rays, with a note on the taxonomy of the parasite. Parasitology 54: 337344.

Whittington I.D., Deveney M.R., Wyborn S.J. 2001: A revision of Benedenia Diesing, 1858 including a redescription of B. sciaenae (van Beneden, 1856) Odhner, 1905 and recognition of Menziesia Gibson, 1976 (Monogenea: Capsalidae). J. Nat. Hist. 35: 663-777.

Whittington I.D., KeARn G.C. 2008: Trimusculotrema heronensis sp. nov. (Monogenea: Capsalidae) from the skin of the pink whipray Himantura fai (Elasmobranchii: Dasyatidae) from Heron Island, Queensland, Australia. Acta Parasitol. 53: 251-257.

Whittington I.D., Kearn G.C. 2009: Two new species of entobdelline skin parasites (Monogenea, Capsalidae) from the blotched fantail ray, Taeniura meyeni, in the Pacific Ocean, with comments on spermatophores and the male copulatory apparatus. Acta Parasitol. 54: 12-21.

Accepted 18 December 2008 